\title{
Veritabanı Organizasyonu Dersinde Elektronik Portfolyo Uygulamalarının Akademik Başarıya Etkisi*
}

\section{The Effect of Electronic Portfolio Applications on Academic Success in Database Organization Course}

\author{
Dr. Öğr. Üyesi Gülçin ZEYBEK (iD) 1
}

\begin{abstract}
$\ddot{\mathbf{O} z}$
Araştırmanın amacı, Meslek Lisesi Bilişim Teknolojileri Alanı 11. sınıf "veritabanı organizasyonu" dersinde e-portfolyo kullanımın öğrencilerin akademik başarılarına etkisini tespit etmek ve e-portfolyo uygulamalarına ilişkin öğrenci görüşlerini belirlemektir. Ön test - son test kontrol gruplu deneysel desen ile yürütülmüş olan araştırmanın çalışma grubunu 2016-2017 öğretim yılında Karaman ilinde bir meslek lisesinin Bilişim Teknolojileri Alanı 11. sınıfında öğrenim görmekte olan öğrenciler oluşturmuştur. Seçkisiz yöntemle belirlenmiş olan deney ve kontrol grupları 14' er kişiden oluşmaktadır. Deney grubunda 10 hafta süre ile e-portfolyo uygulamaları yapılırken, kontrol grubunda "Bilişim Teknolojileri Alanı Çerçeve Öğretim Programı” kapsamında mevcut uygulamalara devam edilmiștir. Araştırmacı tarafından geliştirilmiş başarı testi, öntest ve sontest olarak öğrencilere uygulanmıştır. Deneysel süreç bitiminde, yarı yapılandırılmış görüşme formu aracılığıyla uygulamalara ilişkin öğrenci görüşleri belirlenmeye çalışılmıştır. Araştırmanın nicel verilerini değerlendirmek amacıyla betimsel istatistik teknikler ve ilişkisiz ölçümler için Mann Whitney-U testi kullanılmıştır. Görüşme formu aracıllğıyla elde edilen nitel veriler ise, betimsel analiz tekniği kullanılarak analiz edilmiştir. Araștırmanın nicel bulguları incelendiğinde, deney grubunun sontest ve erişi puan ortalamalarının, kontrol grubunun sontest ve erişi puan ortalamalarından anlamlı düzeyde yüksek olduğu görülmüştür. Ayrıca araştırmaya katılan öğrenciler, e-portfolyo uygulamalarına ilişkin genel olarak olumlu görüș belirtmişlerdir. Araştırmadan elde edilen bulgular, ilgili alanyazın doğrultusunda yorumlanarak, uygulamaya ve gelecekte yapılabilecek çalışmalara ilişkin çeşitli önerilerde bulunulmuştur.
\end{abstract}

Anahtar Kelimeler: Elektronik portfolyo, öğrenci ürün dosyası, öğrenci gelişim dosyası, alternatif değerlendirme, öğretim yöntemleri

Makale Türü: Araştırma

\begin{abstract}
The aim of the research is to identify the effect of e-portfolio on the academic achievement of students in the "database organization" course and to determine student opinions on the applications. The research was carried out with experimental design with pre-test and post-test control groups. The study group was established in the 11th grade of Information Technologies Department of a vocational high school in Karaman province in the 2016-2017 academic year. While the e-portfolio applications were made for 10 weeks in the experimental group, the existing applications were continued in the control group. The achievement test developed by the researcher was applied to the students as pretest and posttest. At the end of the experimental period, students' opinions regarding the applications were determined through the semistructured interview form. Descriptive statistics and Mann Whitney-U test for independent samples were used to evaluate the quantitative data of the study. Qualitative data were analyzed using descriptive analysis technique. When the findings of the study were examined, it was seen that the average of posttest and

\footnotetext{
*Bu çalışmanın ilk hali 23-25 Mart 2018 tarihinde Afyonkarahisar'da düzenlenen Uluslararası Bilim ve Eğitim Kongresi’nde sözlü bildiri olarak sunulmuştur.

${ }^{1}$ Karamanoğlu Mehmetbey Üniversitesi, Eğitim Fakültesi, gulcinzeybek@km.edu.tr.
}

Atıf için (to cite): Zeybek, G. (2019). Veritabanı Organizasyonu Dersinde Elektronik Portfolyo Uygulamalarının Akademik Başarıya Etkisi. Afyon Kocatepe Üniversitesi Sosyal Bilimler Dergisi, 21(4), 1045-1058. 
achievement points of the experimental group was significantly higher than the control group's. Additionally, the students who participated the study had positive opinion on e-portfolio applications. Findings of the research were interpreted and various suggestions were made.

Keywords: Digital portfolio, student product file, student development file, alternative assessment, teaching methods

Paper Type: Research

\section{Giriş}

Eğitime ilişkin yeni yaklaşımları temel alan programlarda öğrencinin, okul dışındaki gerçek dünyaya uyum sağlamasını kolaylaştıracak yeterlikleri kazanmış olması hedeflenmekte ve bu hedefe ulaşmak için programların hayat ile ilişkilendirilmeleri gerekmektedir. Bireysel farklılıkları göz önünde bulunduran ve öğrenci merkezli öğrenme ve öğretme yaklaşımlarını benimseyen günümüz eğitim programları, ölçme ve değerlendirme konusunda da öğrencilerin bilgi, beceri ve tutumlarını bir bütün olarak ele alan çoklu değerlendirmeyi gerektirmektedir (Demirel, 2008).

Yazılı yoklamalar, sözlü sınavlar, çoktan seçmeli testler, kısa cevaplı testler, eşleştirmeli testler, doğru yanlış testleri gibi geleneksel ölçme araçları, ölçme sonuçlarının nesnel ve güvenilir olmasını sağlamakta, ancak gerçek yaşamla doğrudan ilişkili olmayan durumlara dayanmaktadır. Günümüz öğrencilerinden beklenense, gerçek yaşamda karşılaşacakları problemleri, çeşitli kaynak ve materyalleri kullanarak çözmeleridir. Geleneksel değerlendirme yöntemleri, eğitimde beklenen bazı özellikleri değerlendirmede yetersiz kalmaktadır. $\mathrm{Bu}$ nedenle, geleneksel değerlendirmeleri tamamlayacak alternatif değerlendirme yöntemlerine ihtiyaç duyulmaktadır. Performansa dayalı değerlendirme veya tamamlayıcı değerlendirme olarak da adlandırılan bu tür değerlendirmelerde, öğrenme ürünlerinin yanında öğrenme süreci de dikkate alınmaktadır (Kutlu, Doğan ve Karakaya, 2008).

Alternatif değerlendirme teknikleri arasında en sık kullanılanlardan biri, öğrenci ürün dosyası ya da öğrenci gelişi̇m dosyası olarak da adlandırılan portfolyodur. Portfolyo, öğrencilerin çeşitli alanlardaki çalışmalarını, verdikleri emeği ve geride bıraktıkları aşamaları belirten çalışmalarının amaçlı bir birikimidir (Paulson, Paulson ve Meyer, 1991). Öğrenme ve öğretme sürecine dair etkinliklerin bir araya getirilip yansıtma yapılmasıyla oluşturulan portfolyo aracılığıyla öğrenci "ne öğrenirim" ve "bunu nasıl gösteririm" sorularını yanıtlamaya çalışır (Demirel, 2008).

Portfolyo değerlendirmede, öğrencinin portfolyoyu hazırlama süreci ve bu sürecin sonunda ortaya çıkan ürün üzerinden değerlendirme yapılır (De Fine, 1992). Diğer yandan öğrenciler portfolyo hazırlarken, çalıştıkları konuları da öğrenirler (Atılgan, Doğan ve Kan, 2014). Kısaca portfolyo, öğrenme ile değerlendirmeyi, süreç ile ürünü bir araya getirir. Portfolyoyu diğer değerlendirme türlerinden ayıran bir diğer özellik, değerlendirmeye ilgili tüm kesimlerin katılmasıdır. Çoğu değerlendirme türünde ölçme ve değerlendirme sadece öğretmenler tarafından yapılırken, portfolyoda değerlendirmeye öğrencinin kendisi, arkadaşları ve ailesi de katılabilmektedir. Kişinin kendi çalışmalarını belli ölçütlere dayanarak değerlendirmesi öz değerlendirme, öğrencilerin yine belli ölçütler doğrultusunda birbirlerinin çalışmalarını değerlendirmesi ise akran değerlendirmedir.

Öğrenciler tarafından bireysel olarak hazırlanan portfolyolar, öğrencilerin başarı yönünden karşılaştırılması amacıyla kullanılmaz. Öğrencinin ilgi ve yetenekleri doğrultusunda hazırlanır ve her öğrencinin bireysel olarak değerlendirilmesine olanak sağlar. Uzun süreli olup, öğrencinin performansını yansıtan çok sayıda üründen oluşur. Öğrenciyi araştırmaya, incelemeye, sorgulamaya ve değerlendirmeye yönlendirmesi sebebiyle özellikle bilişsel alanın üst düzey 
davranışlarının (uygulama, analiz, sentez, değerlendirme) kazandırılmasında ve değerlendirilmesinde etkili olabilir.

Basılı olarak hazırlanan ve sunulan geleneksel portfolyolar, bilgi ve iletişim teknolojilerinin gelişmesi ve eğitim ortamlarında hızla yaygınlaşmasıyla birlikte elektronik ortama aktarılmış ve elektronik portfolyo, dijital portfolyo ya da kısaca e-portfolyo da denilen ve bilgisayar ortamında hazırlanıp sunulan portfolyolar, eğitimde kullanılmaya başlamıştır. Eportfolyo, tüm öğrenci çalışmalarının bilgisayarda biriktirilmiş halidir (Chang, 2001). Eportfolyolar, geleneksel portfolyoların genel özelliklerini taşımakla birlikte öğrenmenin tam ve gerçek resmini sunmakta ve portfolyoların taşınabilirliğini artırmaktadırlar (Pullman, 2002). Bu sayede öğrenciler çalışmalarını çoklu ortam şeklinde (metinler, resimler, grafikler, sesler, filmler ve animasyonlar) hazırlayabilmekte ve sunabilmektedirler.

E-portfolyo geleneksel portfolyoya benzemekle birlikte; onlardan farklı olarak çoklu ortam, kelime işlemci, elektronik tablolama, sunu hazırlama, veri tabanı, web tasarım, grafik ve animasyon programları gibi yazılımlardan yararlanmayı gerektirir (Kovalchick, Milman ve Elizabeth, 1998). Ancak geleneksel portfolyolara kıyasla kolay depolanabilme ve taşınabilme özellikleri, tercih edilirliklerini artırmaktadır (Koç, 2010). E-portfolyo ile portfolyoyu hazırlayan öğrencinin çalışmalarına istediğinde ulaşabilmesi, çalışmaları üzerinde değişiklik yapabilmesi, çalışmalarını başkalarıyla paylaşabilmesi ve en önemlisi kendi gelişim sürecini izleyebilmesi mümkün olmaktadır (Hetterscheidt, Pott, Russell ve Tchang, 1992).

Elektronik portfolyo uygulamalarına ilişkin yurt içi ve yurt dışında yapılmış çeşitli araştırmalar mevcuttur. Sanalan ve Altun (2002) ABD' de gerçekleştirmiş oldukları çalışmalarında, e-portfolyoyu bir veritabanı uygulaması olarak kullanmışlardır. Öğrenciler, uygulamanın öğretmen ile öğrenci arasındaki iletişimi hızlandırdığını, dosyaların saklanmasında elverişli bir ortam hazırladığını ve kaybolma korkusunu azalttığını, çalışmaları herhangi bir bellekte toplamak zorunluluğunu ortadan kaldırdığını, dersi daha ilginç kıldığını, istenildiğinde önceki çalışmalara erişim ve paylaşım imkanı sunduğunu, doğrudan bilgisayarda hazırlanabildiği için ödev teslim sürecini kısalttığını ifade etmişlerdir. Mason, Pegler ve Weller (2004)' in çalışmasında, e-protfolyo yazılımını kullanan öğrenciler, bu değerlendirme yazılımının kendi kariyerleri açısından önemli olan çalışmaların düzenlemesinde yararlanılabilecek bir uygulama olduğunu, bu nedenle de yaşam boyu öğrenmeyi desteklediğini ifade etmişlerdir. Korkmaz ve Kaptan (2005) tarafından yapılan araştırma sonuçları, e-portfolyo değerlendirmenin fen eğitiminde öğrenci özelliklerini saptamak, öğrenme ve öğretme sürecini zenginleştirmek ve bilimsel gelişmeyi takip etmek için kullanılabileceğini ortaya koymuştur. Koçoğlu (2006)' nun, geleneksel portfolyo ve e-portfolyoyu bir arada kullandığı çalışmasının sonuçları, portfolyo hazırlama sürecinin, zaman tüketimi gibi olumsuz yönlerinin yanında, öğrenmede işbirliği gerçekleştirme gibi olumlu tarafları bulunduğunu, e-portfolyo hazırlama sürecinde öğrencilerin teknolojiden yararlanma becerileri ve teknoloji kullanımına yönelik olumlu yaklaşımlarının arttığını göstermiştir. Özyenginer (2006)' in, bilgisayar dersinde e-portfolyo kullanımı üzerine yaptığı çalışma sonucunda öğrenciler, çalışmanın başında geçmişte benzer bir çalışma yapmadıkları için endişelendiklerini; ancak çalışma sırasında ve bilhassa sonrasında bu kaygılarının ortadan kalktığını; görsel öğelerle çalışma, araştırma yapma, kendi kendine öğrenme, kendine güven duygusu kazanma, öz-değerlendirme yapma, zamanı etkili kullanma, öğrenme sürecinde sorumluluk alma ve yaratıcı düşünme bakımından geliştiklerini belirtmişlerdir. Yeşilova (2011) tarafindan yapılan araştırma sonucunda elde edilen bulgular da benzer niteliktedir. Çalışma, öğrencilerin sürecin başında isteksizlik duyduklarını; ancak zamanla fikirlerinin değiştiğini, e-portfolyo geliştirmeyi ilgi çekici olarak değerlendirdiklerini, öğrenmeyi sağlamada etkili bulduklarını ortaya koymuştur. Çayırcı (2009)' nın 7. sınıf bilişim teknolojileri dersinde yürütmüş olduğu çalışmada, e-portfolyonun uygulamaları düzenli şekilde saklamayı sağladığından, çoklu ortam unsurlarıyla çalışma olanağı verdiğinden ve öğrencilere başarı duygusunu tattırdığından dolayı faydalı görüldüğü ortaya çıkmıştır. Lopez-Fernandez ve Rodriguez-Illera (2009)' nın gerçekleştirdiği çalışmada öğrencilerin, elektronik-portfolyo 
yöntemini kullanmaktan memnun oldukları ve elektronik-portfolyoyu yapmış oldukları çalışmaları saklamak ve yönetmek amacıyla kullanılabilecek faydalı bir araç olarak benimsedikleri görülmüştür. Gömleksiz ve Koç (2010) tarafından gerçekleştirilmiş olan çalışma sonucunda bilgisayar okuryazarlığı öğretiminde elektronik-portfolyo kullanımının öğrencilerin teorik bilgi düzeyleri üzerinde etkisinin olmadığı, ancak uygulama becerilerinin gelişmesinde olumlu etkisinin olduğu ve e-portfolyo uygulamalarının öğrencilerin öz değerlendirmelerine olumlu yansıdı̆̆ı görülmüştür. Ayrıca öğrencilerin sürece yönelik olumlu tutum geliştirdikleri de araştırma sonucunda ortaya çıkmıştır. Yine Koç (2010) tarafından yapılan araştırma sonucunda öğrenciler, e-portfolyo sürecine ilişkin olarak, sürecin kendilerini araştırmaya sevk etme, sorumluluk duygusu kazandırma, organize ve düzenli olmalarına katkı sağlama açısından olumlu görüşler bildirmişlerdir. Öğmen (2011)' in araştırmasının sonuçları katılımcıların büyük kısmının elektronik-portfolyo çalışmasını ilgi çekici bulduklarını; bilgisayar ortamında hazırlanan ödevlerin, katılımcılara yeni öğrenme stratejileri kazandırdığını göstermiştir. Salinas, Marin ve Escandell (2011) tarafindan yapılan araştırmada, elektronik-portfolyo yazılımı kullanan öğrencilerin yardımlaşmalarının arttığı, grupla gerçekleştirilen ödevlerdeki başarılarının yükseldiği ve yaptıkları çalışmaları portfolyo için bir araya getirmenin önemini kavradıkları ortaya çıkmıştır. Barış ve Tosun (2013) gerçekleştirilmiş olan araştırma sonucunda elektronikportfolyo destekli eğitim sürecinin öğrenci başarısını pozitif yönde etkilediği sonucuna varılmıştır. Kutlu, Polat ve Döşlü (2014)' nün, ortaöğretim düzeyinde bilgi ve iletişim teknolojileri dersinde yapmış olduğu çalışma sonucunda, öğrenciler çalışmayı sevdiklerini, yeni şeyler öğrendiklerini, süreçte araştırma yapma ve işbirliği içerisinde bulunma gereği duyduklarını belirtmişlerdir. Öğrencilerin büyük kısmı web tabanlı portfolyonun sayısal derslerden çok sözel derslerde kullanılmasını önerirken, tamamı uygulamayı tekrarlamak istediklerini belirtmişlerdir. Öğrenciler çoğunlukla, web tabanlı portfolyolarından yeterli düzeyde puan almışlardır. Aktay ve Gültekin (2014) ise web tabanlı portfolyoyu ilköğretim düzeyinde uygulamışlardır. Araştırma sonucunda öğretmen ve öğrencilerin çoğu webfolyoyu geleneksel portfolyolardan daha verimli bulmuşlardır. Tur ve Marin (2014)' in gerçekleştirdiği çalışmada, elektronik-portfolyo üzerinden sınıf arkadaşları ile yorumlarını paylaşan öğrencilerin, elektronik-portfolyo puanlarının daha yüksek olduğu ve yapılan yorumların sosyal paylaşımı artırdığı görülmüştür. Özgür (2016)' ün, araştırmasının sonucunda bir sosyal ağ sitesine entegre edilen e-portfolyo yazılımını kullanan öğrencilerin eğitim sonundaki akademik başarı ve kalıcılık testi puanlarının diğerlerine oranla anlamlı derecede yüksek olduğu görülmüştür. Demir ve Kutlu (2016) tarafindan yapılan araştırma sonuçları, elektronik-portfolyoya dayalı araştırma becerileri eğitiminin, öğrencilerin araştırma becerilerini kullanım düzeylerini anlamlı düzeyde artırdığını ve araştırma konusundaki tutum ve ilgilerinin geliştirilmesinde etkili olduğunu göstermiş̧ir. Başarı ve kalıcılık bakımından Erten (2015), çalışmasında benzer sonuçlara ulaşmıştır. Akademik başarı ve tutum açısından Arap (2008), Barış (2011) ve Alan (2014) tarafindan yapılan araştırmalarda olumlu sonuçlar elde edilmiş; Kazan (2006), Gülbahar ve Köse (2006), Demirli (2007), Çukurbaşı ve Kıyıcı (2018)' nın yaptıkları çalışmalarda da e-portfolyo uygulamalarına ilişkin olumlu görüşler ortaya çıkmıştır.

\section{Araştırmanın Amacı ve Önemi}

E-portfolyoya ilişkin yurt dışında uzun zamandır çalışmalar yapılmakta iken, ülkemizde yapılandırmacılık temelli öğretim programlarının uygulamaya konulmasıyla birlikte, 2006 yılından itibaren çeşitli çalışmalara rastlanmaktadır. İlgili alanyazın incelendiğinde, ilköğretimden yükseköğretime kadar her düzeyde e-portfolyo uygulamalarının akademik başarı, öğrenilenlerin kalıcılığı, ilgi, tutum ve motivasyon açısından olumlu sonuçlar ortaya koyduğu, ancak halen yeterli sayıda çalışma bulunmadığı görülmektedir. Araştırmanın, diğerlerinden farklı olarak meslek lisesinde yürütülmüş bir çalışma olması, nicel ve nitel yöntemleri bir araya getirmesi, öz değerlendirme ve akran değerlendirmeye önemle yer verilmesi ve değerlendirmenin de ötesinde, bilhassa öğretim amaçlı kullanılmış olması sebebiyle alana katkı getireceği düşünülmektedir. 
Bu araştırmanın amacı, Meslek Lisesi Bilişim Teknolojileri Alanı 11. sınıf "veritabanı organizasyonu" dersinde e-portfolyo kullanımın öğrencilerin akademik başarılarına etkisini tespit etmek ve e-portfolyo uygulamalarına ilişkin öğrenci görüşlerini belirlemektir. Bu doğrultuda araştırmanın hipotezleri ve alt problemleri aşağıda verilmiştir.

\subsection{Araştırmanın Hipotezleri}

1. Deney ve kontrol grubu öğrencilerinin deneysel uygulama öncesi başarı testinden (öntest) aldıkları puan ortalamaları arasında anlamlı bir farklılık bulunmamaktadır.

2. Deney ve kontrol grubu öğrencilerinin deneysel uygulama sonrası başarı testinden (sontest) aldıkları puan ortalamaları arasında deney grubu lehine anlamlı bir farklılık bulunmaktadır.

3. Deney ve kontrol grubu öğrencilerinin deneysel uygulama sonrası erişi (sontest - öntest) puan ortalamaları arasında deney grubu lehine anlamlı bir farklılık bulunmaktadır.

\subsection{Araştırmanın Alt Problemleri}

1. Deney grubu öğrencilerinin e-portfolyo uygulamasına ilişkin görüşleri nelerdir?

\section{Yöntem}

\subsection{Araştırmanın Deseni}

Araştırmanın deseni, öntest-sontest kontrol gruplu seçkisiz deneysel desendir. Araştırma sürecinde deney ve kontrol gruplarında gerçekleştirilmiş işlemler Tablo1' de verilmiştir.

Tablo 1. Deney ve kontrol grubunda uygulanmış olan işlemler

\begin{tabular}{cccc}
\hline Grup & Öntest & İşlem & Sontest \\
\hline $\mathrm{D}$ & $\mathrm{O}_{1}$ & $\mathrm{X}$ & $\mathrm{O}_{3}$ \\
\hline $\mathrm{K}$ & $\mathrm{O}_{2}$ & & $\mathrm{O}_{4}$ \\
\hline
\end{tabular}

D: Deney grubu

$\mathrm{K}$ : Kontrol grubu

O1: Deney grubuna uygulanmış olan öntest

O2: Kontrol grubuna uygulanmış olan öntest

$\mathrm{X}$ : Deney grubuna uygulanmış olan deneysel işlem (e-portfolyo uygulamaları)

O3: Deney grubuna uygulanmış olan sontest

O4: Kontrol grubuna uygulanmış olan sontest

\section{2. Çalışma Grubu}

Araştırmanın çalışma grubunu 2016-2017 öğretim yılında Karaman il merkezinde bulunan bir meslek lisesinin Bilişim Teknolojileri Alanı 10. sınıfında öğrenim görmekte olan öğrenciler oluşturmuştur. Deney ve kontrol gruplarının oluşturulmasında basit seçkisiz örnekleme yöntemi kullanılmıştır. Ders yılı başında öğrenciler, meslek derslerinin bilgisayar laboratuvarlarında uygulamalı olarak yürütülebilmesi için seçkisiz yöntemle iki gruba ayrılmıştır. Daha sonra araştırma sürecinin başında bu iki gruptan biri deney, diğeri kontrol grubu olmak üzere seçkisiz olarak belirlenmiştir. Her iki grup 14' er kişiden oluşmaktadır.

\subsection{Veri Toplama Araçları}

Araştırmada öntest ve sontest olarak uygulanmak üzere araştırmacı tarafından bir başarı testi geliş̧irilmiştir. Başarı testi oluşturulurken testin kapsam geçerliğini sağlamak amacıyla dersin öğretim programı ayrıntılı olarak incelenmiş, bilişim teknolojileri öğretmenlerinin görüş ve önerileri alınmış, kapsamı temsil eden davranışları belirlemek üzere belirtke tablosu oluşturulmuş ve bu doğrultuda 24 sorudan oluşan bir test hazırlanmıştır. Hazırlanan testin deneme 
uygulaması, il merkezinde bulunan başka bir meslek lisesinin bilişim teknolojileri alanında öğrenim görmekte olan 116 öğrenci ile yapılmıştır. Madde analizi kapsamında her bir maddenin güçlük indeksi, ayırt edicilik indeksi ve güvenirlik indeksi hesaplanmış, yapılan madde analizi sonrasında 4 soru testten çıkarılmıştır. 20 sorudan oluşan nihai testin ortalama güçlüğü $p j=0,44$; ortalama ayırt ediciliği qj $=0,42$ ve güvenirlik değeri $\mathrm{KR}-20=0,84$ olarak hesaplanmıştır. $\mathrm{Bu}$ bulgulara dayanılarak testin genel olarak orta güçlükte, ayırt ediciliği yüksek ve güvenilir bir test olduğunu söylemek mümkündür.

Nitel verilerin toplanmasında ise yarı yapılandırılmış görüşme formu kullanılmıştır. $\mathrm{Bu}$ form geliştirilirken benzer çalışmalarda kullanılmış görüşme formları incelenmiş ve uzman görüşü doğrultusunda görüşme soruları hazırlanmıştır. Deneysel uygulama sürecinin bitiminde deney grubu öğrencileri ile görüşmeler yapılarak e-portfolyo uygulamalarına ilişkin görüşleri alınmıştır.

\subsection{Uygulama Süreci (Verilerin Toplanması)}

Deney grubunda 10 hafta süre ile e-portfolyo uygulamaları yapılırken, kontrol grubunda "Bilişim Teknolojileri Alanı Çerçeve Öğretim Programı" kapsamında mevcut uygulamalara devam edilmiştir. Bu çalışmada e-portfolyo yöntemi, değerlendirmeden çok öğrenmeyi sağlama amacıyla kullanılmıştır. Yapılması planlanan çalışmalar, 10 hafta süren uygulama sürecinin başında genel hatlarıyla belirlenmiştir. Deney grubundaki bütün öğrenciler, deneysel uygulamanın gerçekleştirildiği 10 hafta boyunca veritabanı organizasyonu dersinde yapmış oldukları çalışmaları bilgisayar laboratuvarında çalıştıkları bilgisayarlarda kronolojik olarak saklamışlar ve belirli periyotlarla geri dönüp tekrar gözden geçirmişlerdir. Biten her uygulamanın ardından öğrenciler, çalışmanın işlem basamakları dikkate alınarak, uzman görüşleri doğrultusunda oluşturulmuş olan dereceli puanlama anahtarları (rubrikler) aracılığıyla hem kendi çalışmalarını (öz değerlendirme) hem de arkadaşlarının çalışmalarını (akran değerlendirme) değerlendirmişlerdir. Daha sonra bu çalışmalar ders öğretmeni tarafından değerlendirilmiştir. Süreç sonunda her bir öğrencinin ilk çalışmasından son çalışmasına kadar bütün uygulamaları gözden geçirilmiş ve öğrencinin gelişimine ilişkin genel bir değerlendirme yapılmıştır.

Araştırmacı tarafından geliştirilmiş başarı testi, deneysel işlemlerden önce (öntest) ve deneysel işlemlerden sonra (sontest) deney ve kontrol gruplarına eş zamanlı uygulanmıştır. Ayrıca deney grubu öğrencileriyle görüşmeler yapılarak deneysel uygulama sürecine ilişkin görüşleri alınmıştır.

\subsection{Verilerin Analizi}

Araştırmanın nicel verilerini değerlendirmek amacıyla betimsel istatistik teknikler ile deney ve kontrol gruplarının öntest, sontest ve erişi puanlarını karşılaştırmak amacıyla Mann Whitney-U testi kullanılmıştır. Deney ve kontrol gruplarının az sayıda (14) bireyden oluşmuş olması sebebiyle normal dağılım durumuna bakmak için Shapiro-Wilk testi yapılmış ve $p$ değerinin anlamlı (<.05) çıkması üzerine non-parametrik bir test tercih edilmiş̧ir.

$\mathrm{Bu}$ araştırmada görüşme verileri sesli olarak kaydedilmiş, bunun için görüşmenin başında katılımcılardan sözel onay alınmıştır. Görüşmenin yapıldığı gün görüşme verileri araştırmacı tarafından dinlenerek kelime işlemci programında verilerin dökümü yapılmıştır. Son olarak elde edilen nitel veriler, betimsel analiz tekniği kullanılarak analiz edilmiştir. Nitel veriler, başka bir ifadeyle öğrenci görüşleri sunulurken doğrudan alıntılara da yer verilmiştir. Burada öğrenci isimleri yerine Ö1, Ö2 gibi kodlamalar kullanılmıştır.

\section{Bulgular}

\subsection{Araştırmanın Nicel Bulguları}

$\mathrm{Bu}$ bölümde araştırmada kullanılan başarı testinden elde edilen öntest, sontest ve erişi puanlarına ilişkin bulgulara yer verilmiştir. 


\subsubsection{Deney ve Kontrol Grubu Öğrencilerinin Öntest Puan Ortalamalarının Karşılaş̧ırılması}

Tablo 2. Öğrencilerin öntest puanlarının gruba göre Mann Whitney-U testi sonuçları

\begin{tabular}{cccccc}
\hline Grup & $\mathrm{n}$ & $\begin{array}{c}\text { Sira } \\
\text { Ortalamas } 1\end{array}$ & $\begin{array}{c}\text { Sira } \\
\text { Toplam1 }\end{array}$ & $\mathrm{U}$ & $\mathrm{p}$ \\
\hline Deney & 14 & 13,46 & 188,50 & 83,500 & 0,498 \\
\hline Kontrol & 14 & 15,54 & 217,50 & & \\
\hline $\mathrm{p} \leq 0.05$. & & & &
\end{tabular}

Tablo 2 incelendiğinde, deney ve kontrol gruplarının öntest puanları arasında anlamlı bir fark olmadığ1 görülmektedir. Bu bulguya dayanılarak, deney ve kontrol gruplarının, deneysel uygulama öncesi, "veritabanı organizasyonu" dersi akademik başarı ortalamaları bakımından denk oldukları söylenebilir.

\subsubsection{Deney ve Kontrol Grubu Öğrencilerinin Sontest Puan Ortalamalarının Karşılaştırılması}

Tablo 3. Öğrencilerin sontest puanlarının gruba göre Mann Whitney-U testi sonuçları

\begin{tabular}{cccccc}
\hline Grup & $\mathrm{n}$ & $\begin{array}{c}\text { Sira } \\
\text { Ortalamas } 1\end{array}$ & $\begin{array}{c}\text { Sira } \\
\text { Toplami }\end{array}$ & $\mathrm{U}$ & $\mathrm{p}$ \\
\hline Deney & 14 & 17,82 & 249,50 & 51,500 & 0,032 \\
\hline Kontrol & 14 & 11,18 & 156,50 & & \\
\hline $\mathrm{p} \leq 0.05$. & & & & &
\end{tabular}

Tablo 3 incelendiğinde, deney ve kontrol gruplarının sontest puanları arasında deney grubu lehine anlamlı bir farklılık görülmektedir. Bu bulguya dayanılarak, deney grubunda gerçekleştirilen e-portfolyo uygulamalarının "veritabanı organizasyonu" dersinde akademik başarıyı sağlamada mevcut uygulamalara oranla etkili olduğu söylenebilir.

\subsubsection{Deney ve Kontrol Grubu Öğrencilerinin Erişi Puan Ortalamalarının Karşılaştırılması}

Tablo 4. Öğrencilerin erişi puanlarının gruba göre Mann Whitney-U testi sonuçları

\begin{tabular}{cccccc}
\hline Grup & $\mathrm{n}$ & $\begin{array}{c}\text { Sira } \\
\text { Ortalamas1 }\end{array}$ & $\begin{array}{c}\text { Sira } \\
\text { Toplam1 }\end{array}$ & $\mathrm{U}$ & $\mathrm{p}$ \\
\hline Deney & 14 & 19,04 & 266,50 & 34,500 & 0,003 \\
\hline Kontrol & 14 & 9,96 & 139,50 & & \\
\hline $\mathrm{p} \leq 0.05$ & & & &
\end{tabular}

$\mathrm{p} \leq 0.05$.

Tablo 4 incelendiğinde, deney ve kontrol gruplarının erişi (sontest-öntest) puanları arasında deney grubu lehine anlamlı bir farklılık görülmektedir. Bu bulguya dayanılarak, deney grubunda gerçekleştirilen e-portfolyo uygulamalarının "veritabanı organizasyonu" dersinde akademik başarıyı sağlamada mevcut uygulamalara oranla etkili olduğu söylenebilir.

\subsection{Araştırmanın Nitel Bulguları}

$\mathrm{Bu}$ bölümde araştırmada kullanılan yarı yapılandırılmış görüşme formu aracılığıyla elde edilen öğrenci görüşlerine yer verilmiştir.

\subsection{1. Öğrencilerin Yapılan Uygulamanın Daha Önceki Öğrenme ve Öğretme Yöntemlerinden Farklılı̆̆ına İlişkin Görüsşleri}

Araştırmaya katılan öğrenciler, bilişim teknolojileri alan derslerinde genellikle bilgisayar ortamında uygulamalar yaptıklarını, ancak e-portfolyo uygulamaları kapsamında, yaptıkları çalışmaları düzenli olarak, belirli sıra dahilinde bilgisayarda sakladıklarını ve bu sayede geriye dönüp, geçmiş çalışmalarını gözden geçirebildiklerini ve kendi gelişimlerini rahatlıkla takip edebildiklerini ifade etmişlerdir. Ayrıca öğrenciler, daha önce herhangi bir derste öz değerlendirme ya da akran değerlendirme yapmadıklarını, bu yöntemi oldukça farklı bulduklarını ifade etmişlerdir. 


\subsection{2. Öğrencilerin e-Portfolyo Uygulamalarında Keyifli Bulduklart Aşamalara İlişsin Görüssleri}

Araştırmaya katılan öğrencilerin büyük kısmı, uygulamanın her aşamasından keyif aldıklarını ifade ederken, kimi öğrenciler öz değerlendirme ve akran değerlendirme etkinliklerinin kendilerine oldukça ilgi çekici ve zevkli geldiğini belirtmişlerdir.

\subsection{3. Öğrencilerin e-Portfolyo Uygulamalarında Zorlandıkları Aşamalara İlişkin Görüşleri}

Araştırmaya katılan öğrenciler, uygulama sürecinin başında endişe duyduklarını, ancak zaman içerisinde bu endişelerinin ortadan kalktığını, uygulamalarını yapma ve kaydetme konusunda önemli bir zorluk yaşamadıklarını ifade etmişlerdir. Örneğin Ö14; "Bilişim teknolojileri bölümünde ögrenim görmekte olduğumuz için uygulamalarl yapmak, kaydetmek, tekrar açmak, birleştirmek gibi işlemlerde çok zorlanmadık” demiştir. Bunun yanında öğrencilerin büyük kısmı, daha önce hiç öz değerlendirme ve akran değerlendirme yapmadıkları için başlangıçta zorlandıklarını, fakat süreç ilerledikçe değerlendirme yapmanın da kolaylaştı̆̆ını belirtmiş̧lerdir. Bu duruma ilişkin olarak Ö1; "İlk başlarda kendi çalışmamı değerlendirirken de, arkadaşlarımın çalışmalarını değerlendirirken de gereğinden fazla mı puan veriyorum ya da çok mи acımasız davranıyorum diye düşündüm. Fakat çalışmalar ilerledikçe değerlendirme de daha kolay bir hal aldl" şeklinde görüş belirtmiştir. Ayrıca bazı öğrenciler, zaman konusunda sorun yaşadıklarını, ders süresinin kısa olması sebebiyle uygulamaları ancak tamamlayabildiklerini, değerlendirme için az zamanları kaldığını dile getirmişlerdir. Örneğin Ö2; "Veritabanı organizasyonu dersi haftada 2 saatlik bir ders olduğu için uygulamayı vaktinde yetiştirmekte zorlandım. Arkadaşlarımın çalışmalarını değerlendirmek için az zamanım kaldı" demiştir.

\subsubsection{Uygulanan Değerlendirme Yöntemine İlişkin Öğrenci Görüşleri}

Araştırmaya katılan öğrenciler, öz değerlendirme ve akran değerlendirme ile ilk kez karşılaştıklarını, sürecin başında zorlandıklarını, ancak bir yandan da öz değerlendirme ve akran değerlendirmeyi keyifli bulduklarını, akran değerlendirme sayesinde farklı çalışmaları da gördüklerini ve kendi eksiklerini fark edebildiklerini ifade etmişlerdir. Örneğin Ö13; "Akran değerlendirme aşamasında kendi çalışmam dışında başka çalışmaları da görmüş oldum. Böylece yanlış veya eksik yaptı̆̆ım noktaların farkına vardım" ş̧eklinde görüş belirtirken; Ö3; "Arkadaşlarımın çalışmalarını görünce, aslında kendi çalışmamın gayet iyi olduğunu anladım" demiştir.

Bunun dışında öğrenciler, değerlendirme amacıyla dereceli puanlama anahtarları kullanımının, değerlendirmeyi herkes tarafından yapılabilir, anlaşılabilir ve daha tarafsız hale getirdiğini ifade etmişlerdir. Örneğin Ö12; "Rubrikleri kullanmasaydık hem kendi çalışmalarımı, hem de arkadaşlarımın çalışmalarını değerlendirmekte zorlanırdım. Rubrikler bana kılavuz oldu" demiştir. Ö2; "Rubrikler olmasaydı ne kendimin ne de arkadaşlarımın yapılan çalışmaları objektif şsekilde değerlendirebileceğini düşünmezdim" şeklinde görüş belirtmiştir. Ö4; "Rubrikler sayesinde çalışmada nelere dikkat etmem gerektiğini, yani değerlendirme kriterlerini görmüss oldum” diyerek düşüncesini dile getirmiştir.

\subsubsection{Yapmış Oldukları Çalışmalara İlişsin Öğrenci Görüşsleri}

Araştırmaya katılan öğrencilere "Aynı çalışmaları tekrar yapsan neleri değiştirirdin?" sorusu sorulmuştur. Öğrencilerin bir kısmı uygulamaları tekrar yapmaları halinde daha özenli çalışacaklarını, uygulamaları kaydederken daha dikkatli olacaklarını belirtmişlerdir.

\subsubsection{E-Portfolyo Uygulamalarının Öğrenmeye Olan Katkısına İlişkin Öğrenci Görüşleri}

Araştırmaya katılan öğrenciler, e-portfolyo uygulamalarının hem öğrenme hem değerlendirme açısından kendilerine sorumluluk verdiğini, güçlü ve zayıf yanlarını görmelerini sağladığını, kendilerini araştırma yapmaya ve arkadaşlarıyla işbirliği içinde çalışmaya teşvik ettiğini ifade etmişlerdir. Örneğin Ö5; "Ders süresince her zamankinden daha aktiftik. Uygulamadan değerlendirmeye dersin her aşamasında görev ve sorumluluklar aldık" demiştir. Ö11; "Değerlendirme yaparken rubrikleri görmek, çallşmada nelere dikkat etmem gerektiğini 
gösterdi" şeklinde görüş belirtirken; Ö9; "Değerlendirme amacıyla arkadaşlarımın çalışmalarını incelemek, eksik yaptığım noktaları tespit etmemi, bunları gidermemi ve zaylf yönlerimi geliştirmemi sağladı" demiştir. Ö10 ise; "Akran değerlendirme yaparken arkadaşlarımdan daha iyi yaptı̆̆ım şeyleri görmek bu ders konusunda özgüvenimin artmasını să̆ladı" diyerek düşüncesini dile getirmiştir. Ö6; "Uygulamaları yaparken ders modülünün kaynak olarak yeterli olmadiğı durumlarda farklı kaynaklardan araştırma yapmam gerekti, bu da keyifliydi" şeklinde görüş belirtirken; Ö7; "Sinıf içinde uygulamalart yaparken zaman zaman birbirimizden yardım aldık, çalışırken işbirliği yapmış olmanın ögrenmemizi kolaylaştırdığını düşünüyorum” diyerek düşüncesini ifade etmiştir.

\subsubsection{E-Portfolyo Uygulamaları Esnasındaki Öğretmen Rolüne İlişkin Öğrenci Görüşsleri}

Araştırmaya katılan öğrenciler, gerek uygulamalar esnasında, gerekse değerlendirme aşamasında öğretmenden çok öğrencilerin etkin olduğunu, öğretmenin daha çok rehberlik ettiğini ifade etmişlerdir. Ö10; "Derste öğretmenimiz daha çok danışmanlık yaptı, biz ögrenciler ise aktif olan taraftı, ders esnasında sorumluluğun büyük ölçüde bizde olması güzeldi” demiştir. Ö7; "Özellikle değerlendirme aşamasında yetki ve sorumluluğun büyük ölçüde bize verilmesi, kısmen de olsa öğretmen rolüne bürünmüşs olmamız, oldukç̧a farklı ve zevkli bir durumdu” şeklinde görüş belirtmiştir.

\subsubsection{E-Portfolyo Uygulamalarına İlişkin Öğrenci Önerileri}

Araştırmaya katılan öğrencilere "Bu ya da benzer bir uygulamayı tekrar aynı derste ya da farklı derslerde yapmak ister misin? Neden?" sorusu sorulmuştur. Öğrencilerin tamamı uygulamayı tekrar yapmak istediklerini; bir kısmı, meslek derslerinde yapılmasının yararlı olacağını düşündügünü, bir kısmı da, hangi ders olursa olsun böyle bir uygulamanın çok zevkli olabileceğini ifade etmiştir. Örneğin Ö3; "Benzer bir uygulamayı kesinlikle tekrar yapmak isterim, hem çok zevkli, hem de çok verimli olduğuna inanıyorum" demiştir. Ö4; "Meslek derslerinde genellikle bilgisayar ortamında çalışmalar yapıyoruz. O nedenle meslek derslerinde bu tür etkinliklerin daha iyi olabileceği kanısındayım" şeklinde görüş belirtirken, Ö7; "2 saatlik bir derste değil de, haftalık ders saatinin daha fazla olduğu herhangi bir meslek dersinde yapılması daha kolay olabilir" şeklinde düşüncesini ifade etmiştir.

\section{Tartışma, Sonuç ve Öneriler}

Araştırmanın nicel bulguları incelendiğinde, deney ve kontrol gruplarının sontest ve erişi (sontest - öntest) puanları arasında deney grubu lehine anlamlı farklılık görülmüştür. Bu sonuçlara dayanılarak, deney grubunda gerçekleştirilen e-portfolyo uygulamalarının "veritabanı organizasyonu" dersinde akademik başarıyı sağlamada mevcut uygulamalara oranla etkili olduğu yorumu yapılmıştır.

Araştırmanın akademik başarıya ilişkin bulguları, alanyazındaki diğer araştırmaların bulgularıyla da desteklenmektedir. Arap (2008)' in, öğretmenlik uygulaması dersinde öğretmen adaylarıyla yaptığı çalışma sonucunda e-portfolyo uygulamalarının yapıldığı deney grubunun başarı ortalaması, kontrol grubundan yüksek çıkmıştır. Gömleksiz ve Koç (2010), yaptıkları araştırma ile bilgisayar okuryazarlığı öğretiminde e-portfolyo kullanımının öğrencilerin teorik bilgi düzeylerinde herhangi bir etkisi olmadığını, fakat uygulama becerilerinin gelişmesinde etkili olduğunu ortaya koymuşlardır. Barış (2011), e-portfolyonun bir sosyal ağ sitesi içerisinde etkin olarak kullanılabilirliğini araştırdığı araştırmasının sonucunda, e-portfolyo destekli eğitimin öğrencilerin başarılarını olumlu yönde etkilediğini belirlemiştir. Barış ve Tosun (2013), eportfolyo destekli eğitim sürecinin öğrencilerin akademik başarısına etkisini araştırmışlardır. Elde edilen bulgulara göre, deney grubundaki öğrencilerin akademik başarı sontest puanları, kontrol grubundaki öğrencilerinkine göre daha yüksek bulunmuştur. Alan (2014)' In, e-portfolyo yönteminin etkililiğini değerlendirmeyi amaçladığı çalışmasının sonucunda e-portfolyo uygulamalarının gerçekleştirildiği deney grubunun akademik başarı ortalaması kontrol grubundan yüksek bulunmuştur. Erten (2015), çevrimiçi işbirlikli öğrenme ortamında e-portfolyo uygulamaları gerçekleştirmiş ve uygulamaların yapıldığı deney grubunda yer alan öğrencilerin 
kalıc1lık testi sonuçlarının kontrol grubu öğrencilerine göre yüksek olduğu belirlenmiştir. Demir (2016), 6. sınıf öğrencileriyle deneysel bir çalışma yapmış, çalışma sonucunda izleme testlerinden elde edilen puanlar arasında anlamlı farkl1lıklar görülmezken, performans görevlerinden alınan puanlar arasında deney grubu lehine anlamlı farklılıkların olduğu belirlenmiştir. Özgür (2016)' ün yapmış olduğu çalışmada, deney grubunda yer alan ve bir sosyal ağ sitesine entegre edilen eportfolyo yazılımını kullanan öğretmen adaylarının eğitim sonucunda elde ettikleri akademik başarı ve kalıcılık testi ortalama puanlarının diğer grupta yer alan sınıf arkadaşlarına kıyasla anlamlı şekilde yüksek olduğu ortaya çıkmıştır. Demir ve Kutlu (2016) ise, e-portfolyo uygulamalarının 6. sınıf öğrencilerinin araştırma becerileri üzerine etkisini belirlemeye çalışmışlardır. Araştırma sonucunda, deney grubu öğrencilerinin araştırma becerilerini kullanım düzeyleri, kontrol grubuna oranla anlamlı düzeyde artış göstermiştir.

Öğrenci gelişim dosyası, öğrenciyi belirli hedefler doğrultusunda araştırma yapmaya, öğrenme sürecinde etkin olmaya ve her seferinde daha iyi bir ürün ortaya koymaya teşvik etmektedir. Bu yolla, öğrencinin gelişimi baştan sona izlenebilmekte, öğrenci yaptığı çalışmaların niteliğine ilişkin düzenli dönüt alabilmekte ve kendini geliştirebilmektedir. Bütün bunların, bireyin öğrenmesini olumlu yönde etkilemesinin kaçınılmaz olduğu düşünülmektedir.

Araştırmaya katılan öğrenciler, bilişim teknolojileri alan derslerinde genellikle bilgisayar ortamında uygulamalar yaptıklarını, ancak e-portfolyo uygulamaları kapsamında, yaptıkları çalışmaları düzenli olarak, belirli sıra dahilinde bilgisayarda sakladıklarını ve bu sayede geriye dönüp, geçmiş çalışmalarını gözden geçirebildiklerini ve kendi gelişimlerini rahatlıkla takip edebildiklerini ifade etmişlerdir. Öğrenciler, uygulama sürecinin başında endişe duyduklarını, ancak zaman içerisinde bu endişelerinin ortadan kalktığını, uygulamalarını yapma ve kaydetme konusunda önemli bir zorluk yaşamadıklarını belirtmişlerdir. Özyenginer (2006) tarafindan yapılan çalışmada da öğrenciler ilk başlarda daha önce böyle bir çalışma yapmadıkları için endişelendiklerini fakat çalışma sürecinde ve özellikle bitiminde bu endişelerinin yersiz olduğunu anladıklarını ifade etmişlerdir. Çayırcı (2009)' nın araştırmasında öğrenci görüşleri incelendiğinde; e-potfolyonun çalışmaları düzenli bir biçimde biriktirmeyi olanaklı kıldığından, çoklu ortam öğeleriyle çalışma esnekliği sağladığından, başarı duygusunu tattırdığından yararlı bir çalışma olarak görüldüğü sonucuna ulaşılmıştır. Yeşilova (2011) tarafindan yapılan araştırma sonucunda elde edilen bulgular, öğrencilerin başlangıçta isteksizlik yaşasalar da süreç içerisinde görüşlerinin değiştiğini, e-portfolyo geliştirmeyi heyecan verici ve eğlenceli olarak değerlendirdiklerini, kendilerine yeni bilgiler kazandırma yönünde etkili olduğunu düşündüklerini ortaya koymuştur.

Öğrencilerin büyük kısmı, daha önce hiç öz değerlendirme ve akran değerlendirme yapmadıkları için başlangıçta zorlandıklarını, fakat süreç ilerledikçe değerlendirme yapmanın da kolaylaştığını, hatta bu yöntemi oldukça farklı ve ilgi çekici bulduklarını ifade etmişlerdir. Ayrıca öğrenciler, akran değerlendirme sayesinde farklı çalışmaları da gördüklerini ve kendi eksiklerini fark edebildiklerini, değerlendirme amacıyla dereceli puanlama anahtarları kullanımının, değerlendirmeyi herkes tarafindan yapılabilir, anlaşılabilir ve daha tarafsız hale getirdiğini belirtmişlerdir.

Araştırmaya katılan öğrencilerin büyük kısmı, uygulamanın her aşamasından keyif aldıklarını ifade ederken, kimi öğrenciler, zaman konusunda sorun yaşadıklarını, ders süresinin kısa olması sebebiyle uygulamaları ancak tamamlayabildiklerini, değerlendirme için az zamanları kaldığını dile getirmişlerdir. Zaman yetersizliği, Koçoğlu (2006) tarafından yapılmış araştırmada da negatif yön olarak karşımıza çıkmaktadır. Döşlü (2009)' nün çalışmasında da benzer şekilde öğrenciler, yaptıkları çalışmanın zevkli ve eğlenceli olduğunu, çalışmayı çok beğendiklerini belirtmişlerdir. Gömleksiz ve Koç (2010)' un çalışmasında e-portfolyo sürecinin öğrencileri araştırmaya yönlendirmesi, çalışmalarına bireysellik katması ve arkadaşlarıyla paylaşma imkânı sunması, öğrencilerin süreçte en çok hoşlarına giden durumu oluşturmuştur. Ancak aynı çalışmada öğrencilere çalışma için verilen süre yetersiz bulunmuştur. Yeşilova (2011)' nın çalışmasında öğrenciler, e-portfolyo hazırlama sürecinin içerik üzerinde söz hakkına sahip olma, 
araştırma yapma, yeni bilgiler edinme, çalışma sürecinde eğlenme, geçmiş bilgilerini tekrar etme, kendilerini ifade etme yönlerini sevdiklerini belirtirlerken; sürenin uzun olması ve bilgi eksikliğinden kaynaklı sorunlar yaşanması yönlerini sevmediklerini dile getirmiş̧lerdir. Erten (2015) tarafından yapılan araştırmanın nitel boyutuna ilişkin elde edilen sonuçlar uygulanan öğrenme ortamının sosyalleşme, rahatlık, öğrenme, etkileşim, motivasyon, iletişim, tasarruf ve zaman açısından avantajlar sunduğunu ortaya koymuştur. Aynı araştırmada uygulamaların zaman alışı ve öğrenci hazırbulunuşluk düzeyi ise dezavantaj içeren noktalar olarak ön plana çıkmıştır.

Araştırmaya katılan öğrenciler, e-portfolyo uygulamalarının hem öğrenme hem değerlendirme açısından kendilerine sorumluluk verdiğini, güçlü ve zayıf yanlarını görmelerini sağladığını, kendilerini araştırma yapmaya ve arkadaşlarıyla işbirliği içinde çalışmaya teşvik ettiğini ifade etmişlerdir. Koçoğlu (2006)' nun çalışmasında da öğretmen adayları, portfolyolarını hazırlarken kendi öğretim uygulamalarını geliştirecek farklı yolları keşfettiklerini söylemişlerdir. Aynı araştırmanın sonuçları, portfolyo hazırlama sürecinin yardımlaşma ve işbirliğini artırıcı ve öğretmen adaylarının özgüvenlerini geliştirici bir yol olduğunu göstermiştir. Özyenginer (2006) tarafından yapılan çalışma sonucunda ise öğrenciler, araştırma yapma, yeni şeyler öğrenme, özgüven, kendini değerlendirmeyi öğrenme, zamanı kullanma, çalışma ile ilgili sorumluluk hissetme ve yaratıcılık ile ilgili geliştiklerini ifade etmiş̧lerdir. Döşlü (2009)' nün çalışmasında öğrenciler, çalışmada yeni kavramlar öğrendiklerini, araştırma yapma ve arkadaşlarından yardım alma ihtiyacı duyduklarını belirtmişlerdir. Koç (2010) tarafından yapılan araştırmada ise öğrenciler, sürecin kendilerini araştırmaya sevk etmesi, sorumluluk duygusu kazandırması, organize ve düzenli olmalarına katkı sağlaması açısından olumlu görüşler bildirmişlerdir. Kutlu ve diğ. (2014) tarafindan gerçekleştirilmiş olan araştırma sonucunda, öğrencilerin çalışmada yeni kavramlar öğrendikleri, araştırma yapma ve arkadaşlarından yardım alma ihtiyacı duydukları saptanmıştır. Demir ve Kutlu (2016) tarafından yapılan araştırmanın nitel bulguları, öğrencilerin araştırma becerilerinin, araştırmaya olan ilgi ve tutumlarının gelişiminde etkili olduğunu göstermiştir.

Öğrenciler, gerek uygulamalar esnasında, gerekse değerlendirme aşamasında öğretmenden çok öğrencilerin etkin olduğunu, öğretmenin daha çok rehberlik ettiğini ifade etmişlerdir. Öğrencilerin tamamı uygulamayı tekrar yapmak istediklerini; bir kısmı, meslek derslerinde yapılmasının yararlı olacağını düşündüğünü, bir kısmı da, hangi ders olursa olsun böyle bir uygulamanın çok zevkli olabileceğini ifade etmiştir. Döşlü (2009) tarafından yapılan araştırma sonucunda öğrencilerin tümü web tabanlı portfolyo çalışmasını tekrar yapmak istediklerini, çoğunluğu ise sayısal dersler yerine sözel derslerde yapılmasını istediklerini belirtmişlerdir. Erten (2015)'in araştırmasında da uygulanan yöntemin diğer derslerde kullanılıp kullanılmamasına ilişkin öğrenciler teorik, yoruma dayalı ve sözel derslerde kullanılmasının yararlı olacağını belirtmişlerdir.

Yapılan araştırmanın nitel bulgularına bakıldığında, öğrencilerin e-portfolyo uygulamasını genel olarak olumlu buldukları sonucuna ulaşılmıştır. Bu sonuç, alanyazındaki benzer araştırmaların bulgularıyla da paralellik göstermektedir. Örneğin; Kazan (2006), çalışmasında e-portfolyoların kullanımının olumlu karşılandığı sonucuna ulaşmıştır. Gülbahar ve Köse (2006) tarafından yapılan araştırma sonuçları, bu değerlendirme yönteminin öğrenciler tarafından çok benimsendiğini ve öğrenciler açısından farklı yararlar sağladığını ortaya koymuştur. Demirli (2007) tarafından gerçekleştirilmiş olan nitel araştırma sonucunda öğrencilerin, e-portfolyo öğretim sürecini birçok açıdan arzulanan niteliklere sahip bir öğretim süreci olarak algıladıkları ve sürece yönelik oldukça olumlu tutumlar geliştirdikleri görülmüştür. Alan (2014)'ın çalışmasında da e-portfolyo süreci ile ilgili öğrenci, öğretmen ve veli görüşlerinin olumlu olduğu görülmüştür. Çukurbaşı ve Kıyıcı (2018) tarafindan yapılan araştırmanın sonucunda benzer şekilde, e-portfolyoya yönelik tüm öğretmen adaylarının olumlu düşüncelere sahip oldukları görülmüştür. 
Araştırmadan elde edilen nicel ve nitel bulgular, ilgili literatür ışığında yorumlanarak birtakım sonuçlara ulaşılmış ve bu doğrultuda hem uygulamaya hem de yapılabilecek araştırmalara yönelik çeşitli önerilerde bulunulmuştur.

E-portfolyo, öğrencinin önceden belirlenen hedefler doğrultusunda yapmış olduğu çalışmaları içerir. Bu nedenle ders öğretmeni dersle ilgili ayrıntılı plan hazırlamalı ve derste neler yapılacağını önceden belirlemelidir. E-portfolyoda amaç, öğrencinin gelişimini, bireysel olarak ve kendi özellikleri doğrultusunda izlemektir. Öğrencinin başarısını başkalarıyla karşılaştırmamaya ve sınıf içerisinde bir rekabet ortamı yaratmamaya özen gösterilmelidir. Eportfolyo, öğrencinin yüksek düzeyde etkin olduğu bir çalışma şeklidir. Öğrencilere, e-portfolyo çalışmalarına başlamadan önce e-portfolyo hakkında bilgilendirme yapılmalı ve somut örnekler sunulmalıdır. Tüm öğrenci merkezli yöntemlerde olduğu gibi e-portfolyoda da zaman çok önemlidir. Gelişim dosyalarını etkin bir şekilde geliştirebilmeleri için öğrencilere yeterli zaman tanınmalıdır. Ayrıca öğrencilerin çalışmaları süresince neler yaşadığını ve hem kendi çalışmaları hem de arkadaşlarının çalışmalarıyla ilgili neler düşündüğünü öğrenmek için onlara konuşma firsatı yaratılmalı, düzenli olarak geri bildirimler verilmelidir.

Öğretmenler, eğitimin her kademesinde portfolyo vb. alternatif değerlendirme tekniklerini uygulamaları konusunda teşvik edilmelidir. Özelikle performans değerlendirmede eportfolyoların bir değerlendirme ve dönüt aracı olarak kullanılmasının öğretmenler açısından kolaylaştırıcı olacağı düşünülmektedir.

Bu çalışmada e-portfolyo uygulamalarının akademik başarıya olan etkisi ve uygulamaya ilişkin öğrenci görüşleri belirlenmeye çalışılmıştır. Öğrenci merkezli yöntemlerin kalıcı öğrenme sağladığı araştırmalarla kanıtlanmıştır. Akademik başarı yanında öğrenilenlerin kalıcılığı da test edilebilir. Ayrıca e-portfolyo uygulamalarında öğrencinin ailesi de sürece dahil edilebilmektedir. $\mathrm{Bu}$ doğrultuda öğretmen ve veli görüşlerinin de alınması etkili olabilir.

E-portfolyo uygulamaları bilgisayar ortamında yapılmaktadır. Bilgisayarı eğitim ortamına kolaylıkla entegre etmek için ve ögrencilerin bilgisayar kullanım becerilerini artırmak için de e-portfolyo kullanılabilir. Bunlara ek olarak öğrencilerin bilgisayara karş1 tutumları ölçülebilir. İnternetin vazgeçilmez bir öğretim aracı olduğu günümüzde web tabanlı portfolyolardan yararlanılabilir. E-portfolyonun, sosyal ağ sitelerine entegre edilmesiyle, sosyal ağların eğitimde verimli şekilde kullanılması sağlanabilir. E-portfolyonun önemli bir özelliği de bireysel olmasıdır. Bundan dolayı öğrencilere araştırma yapma ve kendi kendine öğrenme becerisi kazandırmada da kullanılabilir.

$\mathrm{Bu}$ çalışma 10 hafta süreyle gerçekleştirilmiştir. Ancak portfolyolar uzun vadeli çalışmalardır. En az bir dönem sürecek çalışmalar öğrencinin gelişiminin izlenmesi açısından daha etkili olabilir. E-portfolyo gerek öğrenme, gerekse değerlendirme amaciyla her düzeyde uygulanabilecek bir yöntemdir. Bu çalışmada lise düzeyinde uygulanmıştır. İlkokul, ortaokul ve yükseköğretim düzeylerinde de çalışmalar yapılabilir. Ayrıca portfolyo vb. alternatif değerlendirme tekniklerine ilişkin geniş katılımlı tarama çalışmaları yapılabilir.

\section{Kaynakça}

Aktay, S. ve Gültekin, M. (2014). İlköğretimde Webfolyo Uygulaması: Öğretmen ve Öğrenci Görüşleri, Illköğretim Online, 13(3): 806-819.

Alan, S. (2014). İlköğretim 4. ve 5. Sinıflarda e-Portfolyo Kullanımının Değerlendirilmesi, Necmettin Erbakan Üniversitesi Eğitim Bilimleri Enstitüsü, Doktora Tezi, Konya.

Arap, B. (2008). Dil Öğretmeni Ĕgitiminde Öğretmen Adayları İçin Elektronik Portfolyo Kullanımı, Mersin Üniversitesi Sosyal Bilimler Enstitüsü, Yüksek Lisans Tezi, Mersin. 
Atılgan, H., Doğan, N. ve Kan, A. (2014). Eğitimde Ölçme ve Değerlendirme (Ed: H. Atılgan), Ankara: An1 Yayıncilik.

Barış. M. F. (2011). Bir Sosyal Ă̆ Sitesine e-Portfolyonun (Elektronik Gelişim Dosyasi) Entegre Edilerek Uygulanması ve Sonuçlarının İncelenmesi, Trakya Üniversitesi Fen Bilimleri Enstitüsü, Doktora Tezi, Edirne.

Barış, M. F. ve Tosun, N. (2013). Influence of e-Portfolio Supported Education Process to Academic Success of the Students, Social and Behavioral Sciences, 103: 492-499.

Çayırcı, N. Y. (2009). Elektronik Gelişim Dosyası İlköğretim 7. Sinıf Bilişim Teknolojileri Dersi Örneği, Dokuz Eylül Üniversitesi Eğitim Bilimleri Enstitüsü, Yüksek Lisans Tezi, İzmir.

Chang, C. (2001). A Study on the Evaluation and Effectiveness Analysis Of Webbased Learning Portfolio (WBLP), British Journal of Educational Technology, 32(4): 435-458.

Çukurbaşı, B. ve Kıyıcı, M. (2018). Öğretmen Adaylarının Elektronik Portfolyoya Yönelik Görüşlerinin İncelenmesi: Weebly Örneği, İnönü Üniversitesi Eğitim Fakültesi Dergisi, 19(1): 01-14.

De Fine, A. A. (1992). Portfolio Assessment: Getting Started, New York: Scholastic Inc.

Demir, B. P. (2016). Elektronik Portfolyo Uygulamalarının Ortaokul 6. Sinıf Öğrencilerinin Araştırma Becerilerine Etkisi, Ankara Üniversitesi Eğitim Bilimleri Enstitüsü, Doktora Tezi, Ankara.

Demir, B. P. ve Kutlu, Ö. (2016). The Effect of Electronic Portfolio Applications on 6th Graders' Research Skills, Education and Science, 41(188): 227-253.

Demirel, Ö. (2008). Öğretim Illke ve Yöntemleri, Öğretme Sanatı, Ankara: Pegem Akademi Yayıncilik.

Demirli, C. (2007). Elektronik Portfolyo Ögrretim Sürecinin Öğrenen Tutumlarına ve Öğrenme Algılarına Etkisi, Fırat Üniversitesi, Sosyal Bilimler Enstitüsü, Doktora Tezi, Elazı ğ.

Döşlü, A. (2009). Ortaöğretim 10. Sinıf Bilgi ve İletişim Teknolojileri Dersinde Web Tabanlı Portfolyo Kullanımı -Adana İlinde Bir Çalışma-, Çukurova Üniversitesi Sosyal Bilimler Enstitüsü, Yüksek Lisans Tezi, Adana.

Erten, P. (2015). Çevrimiçi İşbirlikli Öğrenme Ortamında e-Portfolyo Uygulamasının Akademik Başarıya, Tutumlara, Motivasyona ve Kalıcılığa Etkisi, Fırat Üniversitesi Eğitim Bilimleri Enstitüsü, Doktora Tezi, Elazığ.

Gömleksiz, M. N. ve Koç, A. (2010). Bilgisayar Okuryazarlığı Becerisi Ediniminde e-Portfolyo Sürecinin Öğrenen Performansına ve Tutumlarına Etkisi, Erzincan Eğitim Fakültesi Dergisi, 12(2): 75-96.

Gülbahar, Y. ve Köse, F. (2006). Öğretmen Adaylarının Değerlendirme İçin Elektronik Portfolyo Kullanımına İlişkin Görüşleri, Ankara Üniversitesi Eğitim Bilimleri Fakültesi Dergisi, 39(2): 75-93.

Hetterscheidt, J., Pott, L., Russell, K. ve Tchang, J. (1992). Using the Computer as a Reading Portfolio. Educational Leadership 49(8): 73-82.

Kazan, Z. (2006). Elektronik Gelişim Dosyasının Eğitim Amaçlı Tasarlanması ve Öğretmenlik Uygulaması Dersinde Kullanımının Değerlendirilmesi, Ankara Üniversitesi Eğitim Bilimleri Enstitüsü, Yüksek Lisans Tezi, Ankara.

Koç, A. (2010). Bilgisayar Okuryazarlı̆̆ Becerisi Ediniminde E-Portfolyo Sürecinin Öğrenen Performansina ve Tutumlarına Etkisi, Fırat Üniversitesi Sosyal Bilimler Enstitüsü, Yüksek Lisans Tezi, Elazı ̆. 
Koçoğlu, Z. B. (2006). Portfolyoların İngilizce Eğitimi Ana Bilim Dalı Öğretmen Adaylarının Mesleki Gelişimlerindeki Rolü: Bir Durum Çalışmasl, Boğaziçi Üniversitesi Sosyal Bilimler Enstitüsü, Doktora Tezi, İstanbul.

Korkmaz, H. ve Kaptan, F. (2005). Fen Eğitiminde Öğrencilerin Gelişimini Değerlendirmek İçin Elektronik Portfolyo Kullanımı Üzerine Bir İnceleme. The Turkish Online Journal of Educational Technology - TOJET, 4(1): 101-106.

Kovalchick, A., Milman, N. B., ve Elizabeth, M. (1998). Instructional Strategies for Integrating Technology: Electronic Journals and Technology Portfolios as Facilitators for Self-Efficacy and Reflection in Preservice Teachers, Proceedings of the Society for Information Technology and Teacher Education $9^{\text {th }}$ International Conference, Washington, DC. (ERIC Reproduction Service: ED421115).

Kutlu, M. O., Polat, Y. ve Döşlü, A. (2014). Ortaöğretim 10. Sınıf Bilgi Ve İletişim Teknolojileri Dersinde Web Tabanlı Portfolyo Kullanımı -Adana İlinde Bir Çalışma, Çukurova Üniversitesi Sosyal Bilimler Enstitüsü Dergisi, 23(1): 336-351.

Kutlu, Ö., Doğan, D. C. ve Karakaya, İ. (2008). Öğrenci Başarısının Belirlenmesi: Performansa ve Portfolyoya Dayalı Durum Değerlendirme, Ankara: Pegem Akademi Yayıncılık.

Lopez-Fernandez, O. ve Rodriguez-Illera, J. L. (2009). Investigating University Students' Adaptation to a Digital Learner Course Portfolio, Computers \& Education, 52: 608-616.

Mason, R., Pegler, C. ve Weller, M. (2004). Ee-Portfolios: An Assessment Tool for Online Course, British Journal of Educational Technology, 35(6): 717-727.

Öğmen, K. (2011). E-Portfolyo Yoluyla Kelime Öğrenimi ve Anadolu Lisesi 9. Sinıf Öğrencilerinin Strateji ve Öğrenir Özerkliği Gelişimine Olan Etkisi, Pamukkale Üniversitesi Sosyal Bilimler Enstitüsü, Yüksek Lisans Tezi, Denizli.

Özgür, H. (2016). Facebook Sosyal Ağına Entegre e-Portfolyo Yazılımının Akademik Başarı ve Öğretim Sürecinde Kullanımına Yönelik Tutuma Etkisi, Sakarya University Journal of Education, 6(1): 38-56.

Özyenginer, E. (2006). Bilgisayar Dersinde Elektronik Portfolyo Yöntemi Kullanımı Üzerine Bir Çalışma, Dokuz Eylül Üniversitesi Eğitim Bilimleri Enstitüsü, Yüksek Lisans Tezi, İzmir.

Paulson, F. L., Paulson, P. R ve Meyer, C. A. (1991). What Makes a Portfolio?, Educational Leadership, 48(5): 60-63.

Pullman, G. (2002). Electronic Portfolios Revisited: The Efolios Project, Computers and Composition, 19: 151-169.

Salinas, J., Marin, V. ve Escandell, C. (2011). A Case of Institutional PLE: Integration of VLE and e-Portfolio for Students, Proceedings of the PLE Conference 2011, 1-16. 10th - 12th July 2011, Southampton, UK.

Sanalan, V. A. ve Altun, A. (2002). Bir Veri Tabanı Uygulaması Olarak Elektronik Portfolyo, Erzincan Ë̆itim Fakültesi Dergisi, 4(1): 11-21.

Tur, G. ve Marin, I. V. (2014). Student Teachers' Attitudes Toward Collaboration in e-Portfolios Built with Web 2.0 Tools, UAE Journal of Educational Technology and eLearning, 5: 58-65.

Yeşilova, E. P. A. (2011). Illköğretim 7. Sinı Öğrencilerinin Öğrenme Stillerine Göre Elektronik Portfolyo Hazırlama Süreçlerine İlişkin Görüşleri, Anadolu Üniversitesi Eğitim Bilimleri Enstitüsü, Doktora Tezi, Eskişehir. 